\author{
О.П. Мельникова, Т.В. Пономарьова \\ Харківський національний університет імені В. Н. Каразіна \\ пл. Свободи, 4, м. Харків, 61022, Україна \\ E-mail: e.p.meln2016@gmail.com, tvponomareva@karazin.ua \\ ORCID: https://orcid.org/0000-0001-5030-0157, https://orcid.org/0000-0002-8872-9888

\section{МОДЕЛЮВАННЯ ЗАЛЕЖНОСТІ РІВНЯ СПОЖИВАННЯ ВІД СПОЖИВЧОГО КРЕДИТУВАННЯ}

Будь-яка фрінансова установа прагне збільшити свої прибутки під час кредитно-інвестиційної діяльності. В сучасних умовах української економіки банки прагнуть поширити свою кредитну експансію за рахунок збільшення споживчого кредитування. Завдяки чому збільшується сукупний платоспроможний попит на споживчі товари та послуги, який стимулює відповідну пропозицію, що у свою чергу сприяє зростанню ВВП та економічному зростанню країни в цілому.

У статті були виявлені основні тенденції у динаміці споживчого кредитування, доходів населення та рівня споживання. Аналіз статистичних даних показав, що за період з 2007 по 2017 роки тенденція темпів зростання споживчих кредитів відображає суттєві спади та підйоми, обумовлені економічними та політичними чинниками, а, починаючи з 2016 року простежується різке збільшення темпів зростання, підґрунтям чого $є$ намагання населення зменшити наслідки інфляції за рахунок збільшення споживчих кредитів. У зв'язку з чим $€$ актуальним дослідження кредитної експансії банків за рахунок споживчого кредитування на українському ринку фінансових послуг і потребує більш детального аналізу.

Під час дослідження найбільшу увагу приділено аналізу залежності рівня споживання від споживчих кредитів та доходів населення із застосуванням статистичних методів. Було доведено відсутність лінійного зв'язку між рівнем споживання та споживчими кредитами в Україні у 2007-2017 роках. У роботі було побудовано та досліджено 2-х факторну економетричну модель залежності рівня споживання від споживчих кредитів та доходів населення України. Висока якість побудованої моделі свідчить про те, що її можна використовувати для прогнозування, а також як підґрунтя для подальшого аналізу та оптимізації кредитної експансії банків України.

Ключові слова: споживчі кредити, рівень споживання, доходи домогосподарств, кредитна експансія. Jel Classification: C15, E21, E51.

Olena Melnykova, Tetiana Ponomarova

V.N. Karazin Kharkiv National University

4 Svobody Sq., 61022, Kharkiv, Ukraine

E-mail: e.p.meln2016@gmail.com, tvponomareva@karazin.ua

ORCID: https://orcid.org/0000-0001-5030-0157, https://orcid.org/0000-0002-8872-9888

\title{
MODELLING OF DEPENDENCY OF THE CONSUMPTION LEVEL ON CONSUMER CREDIT
}

Any financial institution aims to increase its profit during lending and investment activity. In modern conditions of the Ukrainian economy banks aim to expand their credit expansion at the expense of increase of consumer crediting which thereby increases solvent demand for consumer goods and services. The latter stimulates relevant supply which encourages the increase of the GDP and the economical growth of the country as a whole.

The main trends in the dynamics of consumer crediting, the income of the population and consumption level were defined in this article. Analysis of statistical data showed that from 2007 to 2017 the tendency of increasing rates of consumer credits reveals essential ups and downs. They are caused by economical and political factors, and, since 2016 there has been a sharp increase of the growth rates reflecting the attempts of the population to diminish the effects of inflation at the expense of increase of consumer credits. That is why the research of the credit expansion of the banks at the expense of consumer crediting on the financial market of Ukraine requires more detailed analysis.

During the research particular attention was paid to the analysis of the dependency of the consumption level on consumer credits and the income of the population using statistical methods. It was proven that there was no linear relationship between the consumption level and consumer credits in Ukraine in the years 2007-

๑ Мельникова О.П., Пономарьова Т.В., 2019 
2017. Two-factor-based econometric model of the dependency of the consumption level on consumer credits and the income of the population of Ukraine was built up and studied. High quality of the constructed model shows that it can be used for forecasting, as well as background for further analysis and optimization of the credit expansion of the banks of Ukraine.

Key words: consumer credit, consumption level, household income, credit expansion.

JEL Classification: C15, E21, E51.

Е.П. Мельникова, Т.В. Пономарьова

Харьковский национальный университет имени В. Н. Каразина

пл. Свободы, 4, г. Харьков, 61022, Украина

E-mail: e.p.meln2016@gmail.com, tvponomareva@karazin.ua

ORCID: https://orcid.org/0000-0001-5030-0157, https://orcid.org/0000-0002-8872-9888

\section{МОДЕЛИРОВАНИЕ ЗАВИСИМОСТИ УРОВНЯ ПОТРЕБЛЕНИЯ ОТ ПОТРЕБИТЕЛЬСКОГО КРЕДИТОВАНИЯ}

Любое фринансовое учреждение стремится увеличить свою прибыль в процессе кредитноинвестиционной деятельности. В современных условиях украинской экономики банки стремятся расширить свою кредитную экспансию за счет увеличения потребительского кредитования. Благодаря этому увеличивается совокупный платежеспособный спрос на потребительские товары и услуги, который стимулирует соответствуюее предложение, что, в свою очередь способствует увеличению ВВП и экономическому росту страны в целом.

В статье были выявлены основные тенденции в динамике потребительского кредитования, доходов населения та уровня потребления. Анализ статистических данных показал, что за период с 2007 по 2017 гг. тенденция темпов увеличения потребительских кредитов отображает существенные спады и подъемы, которые обусловлены экономическими и политическими факторами, а, начиная с 2016 года прослеживается резкое увеличение темпов роста, в связи со стремлением населения уменьшить последствия инфрляции за счет увеличения потребительских кредитов. В связи с чем является актуальным исследование кредитной экспансии банков за счет потребительского кредитования на украинском рынке фринансовых услуг, которое требует более детального анализа.

В исследовании наибольшее внимание уделено анализу зависимости уровня потребления от потребительских кредитов и доходов населения с применением статистических методов. Было обосновано отсутствие линейной связи между уровнем потребления и потребительскими кредитами в Украине в 2007-2017 гг. В работе была построена и исследована 2-х факторная эконометрическая модель зависимости уровня потребления от потребительских кредитов и доходов населения Украины. Высокое качество построенной модели свидетельствует о том, что ее можно использовать для прогнозирования, а также основой для дальнейшего анализа и оптимизации кредитной экспансии банков в Украине.

Ключевые слова: потребительские кредиты, уровень потребления, доходы домашних хозяйств, кредитная экспансия.

Jel Classification: C15, E21, E51.

Вступ. Головною метою будь-якої фрінансової установи $є$ отримання прибутку під час своєї кредитно-інвестиційної діяльності. У зв'язку з цим банки прагнуть поширити свою кредитну експансію для збільшення своїх прибутків, і найчастіше це відбувається за рахунок збільшення споживчого кредитування, завдяки чому збільшується сукупний платоспроможний попит на споживчі товари та послуги, який стимулює відповідну пропозицію, що, у свою чергу, сприяє зростанню ВВП та економічному зростанню країни в цілому. Таким чином, дослідження кредитної експансії банків на українському ринку фрінансових послуг є актуальним і потребує детального аналізу.

Аналіз досліджень та постановка задачі. Проблемам кредитної діяльності банківського сектору в Україні присвячено багато праць, серед яких можна відзначити дослідження Л. Рябініної (Рябініна, 2015), Н. Дорошенко (Дорошенко, 2018), М. Швайко (Швайко, 2017). Підходи до моделювання показників розкриті в працях Т. Меркулової (Меркулова, Коваль, 2018), К. Мороз (Мороз, 2016). Проте аналіз кредитної експансії банків не розглянуто в повній мірі. На наш погляд, потребує значної уваги дослідження залежності рівня споживання населення від споживчого кредитування та доходів домогосподарств, що дасть змогу банкам оптимізувати свою кредитну експансію.

Метою статті $€$ дослідження залежності рівня споживання від споживчого кредитування населення за допомогою статистичних методів та економетричних моделей. 
Результати дослідження. Трансформація економіки України призвела до позитивної зміни ставлення домогосподарств до придбання товарів та послуг у кредит. Зростання попиту на споживче кредитування посилює кредитну експансію банків, які завжди прагнуть здобути більший прибуток. Аналіз динаміки темпів зростання споживчих кредитів, доходів домогосподарств та рівня споживання наведено у таблиці 1.

Таблиця 1

Аналіз динаміки доходів домашніх господарств, споживчих кредитів та рівня споживання

\begin{tabular}{|c|c|c|c|c|c|c|}
\hline \multirow{2}{*}{ Рік } & \multicolumn{2}{|c|}{$\begin{array}{l}\text { Доходи домашніх } \\
\text { господарств }\end{array}$} & \multicolumn{2}{|c|}{ Споживчі кредити } & \multicolumn{2}{|c|}{$\begin{array}{c}\text { Споживання товарів та } \\
\text { послуг }\end{array}$} \\
\hline & млн. грн. & $\begin{array}{c}\text { темпи } \\
\text { зростання }\end{array}$ & $\begin{array}{l}\text { млн. } \\
\text { грн. }\end{array}$ & $\begin{array}{c}\text { темпи } \\
\text { зростання }\end{array}$ & $\begin{array}{l}\text { млн. } \\
\text { грн. }\end{array}$ & $\begin{array}{c}\text { темпи } \\
\text { зростання }\end{array}$ \\
\hline 2007 & 623289 & - & 115032 & & 509533 & - \\
\hline 2008 & 845641 & 1,36 & 186088 & 1,62 & 695618 & 1,37 \\
\hline 2009 & 894286 & 1,06 & 137113 & 0,74 & 709025 & 1,02 \\
\hline 2010 & 1101175 & 1,23 & 122942 & 0,90 & 838213 & 1,18 \\
\hline 2011 & 1266753 & 1,15 & 126192 & 1,03 & 1030635 & 1,23 \\
\hline 2012 & 1457864 & 1,15 & 125011 & 0,99 & 1194791 & 1,16 \\
\hline 2013 & 1548733 & 1,06 & 137346 & 1,10 & 1304031 & 1,09 \\
\hline 2014 & 1516768 & 0,98 & 135094 & 0,98 & 1316757 & 1,01 \\
\hline 2015 & 1772016 & 1,17 & 104879 & 0,78 & 1568173 & 1,19 \\
\hline 2016 & 2051331 & 1,16 & 101528 & 0,97 & 1840262 & 1,17 \\
\hline 2017 & 2652082 & 1,29 & 122066 & 1,20 & 2359985 & 1,28 \\
\hline
\end{tabular}

Джерело: складено та розраховано авторами за даними статистичної звітності (Держстат України, Національний банк України)

Аналізуючи динаміку темпів зростання наведених на рис.1 показників, можна зробити наступні висновки:

1) темпи зростання доходів домогосподарств та рівня споживання практично співпадають;

2) тенденція темпів зростання споживчих кредитів відображає суттєві спади та підйоми, що, на наш погляд, залежить від економічних та політичних чинників. Так, різкий спад споживчого кредитування у 2009 році обумовлюється всесвітньою економічною кризою, а спад у 2015 році - політичними чинниками України (воєнний конфлікт, зниження безпеки країни), хоча темпи зростання доходів домогосподарств та споживання у цьому році суттєво збільшилися, що обумовлюється значною інфляцією - 143,3\% (Міністерство фінансів України);

3) починаючи з 2016 року, простежується різке збільшення темпів зростання споживчого кредитування. Така схильність населення до споживчого кредитування обумовлена розумінням знецінення грошової маси та спробою через споживчі кредити зменшити наслідки інфляції. Тобто споживче кредитування дає змогу населенню уникнути знецінення реальних доходів за рахунок фіксації вартості товарів та розміру періодичних платежів за кредитом на певний час у разі придбання товарів у розстрочку. Таким чином, зростання вартості товарів у наслідок інфляції ніяк не вплине на споживачів, які придбали цей товар використавши споживчі кредити. 


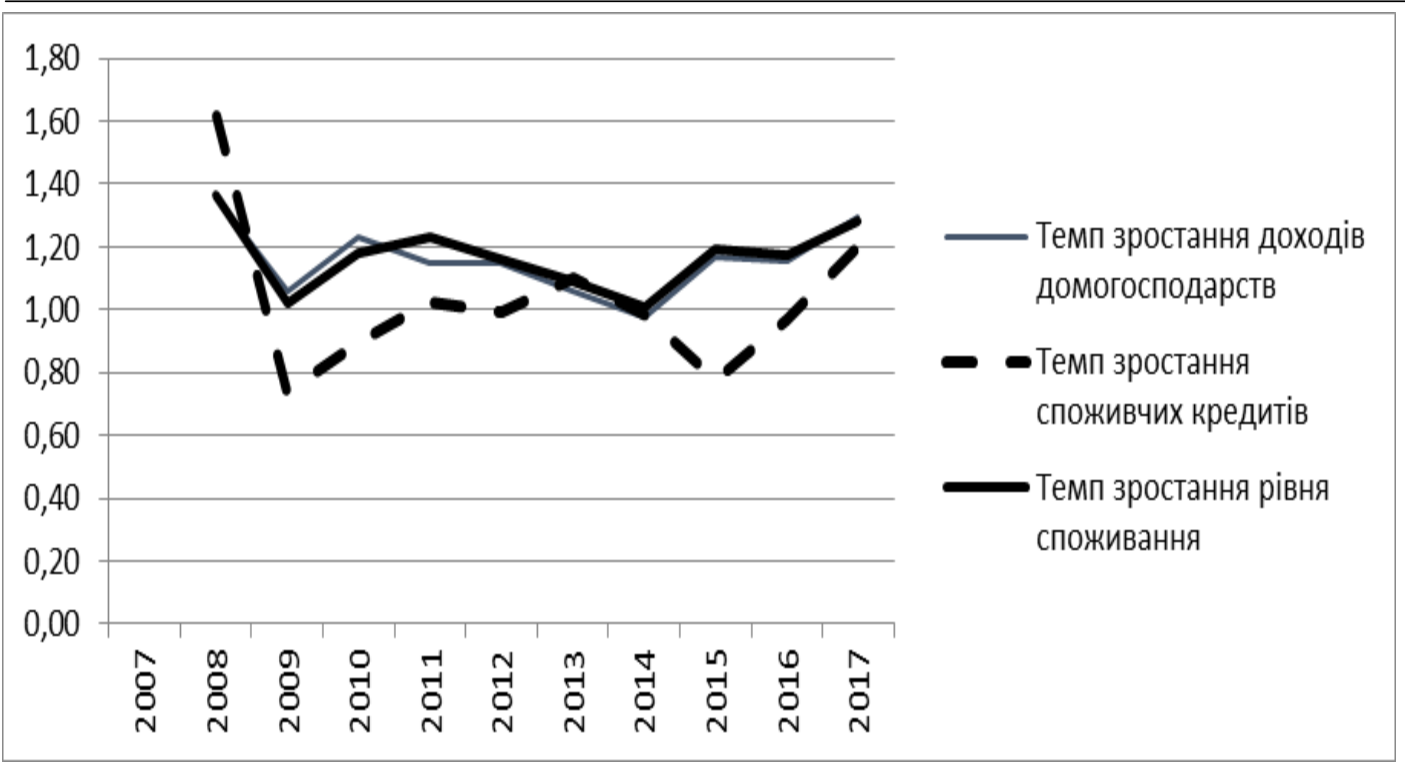

Рис. 1. Динаміка темпів зростання доходів домашніх господарств, споживчих кредитів та рівня споживання

Джерело: побудовано на підставі власних розрахунків автора за даними статистичної звітності (Держстат України, Національний банк України)

Під час дослідження нами було виявлено відсутність лінійної залежності рівня споживання в Україні за 2007-2017 рр. від споживчого кредитування (рис. 2).

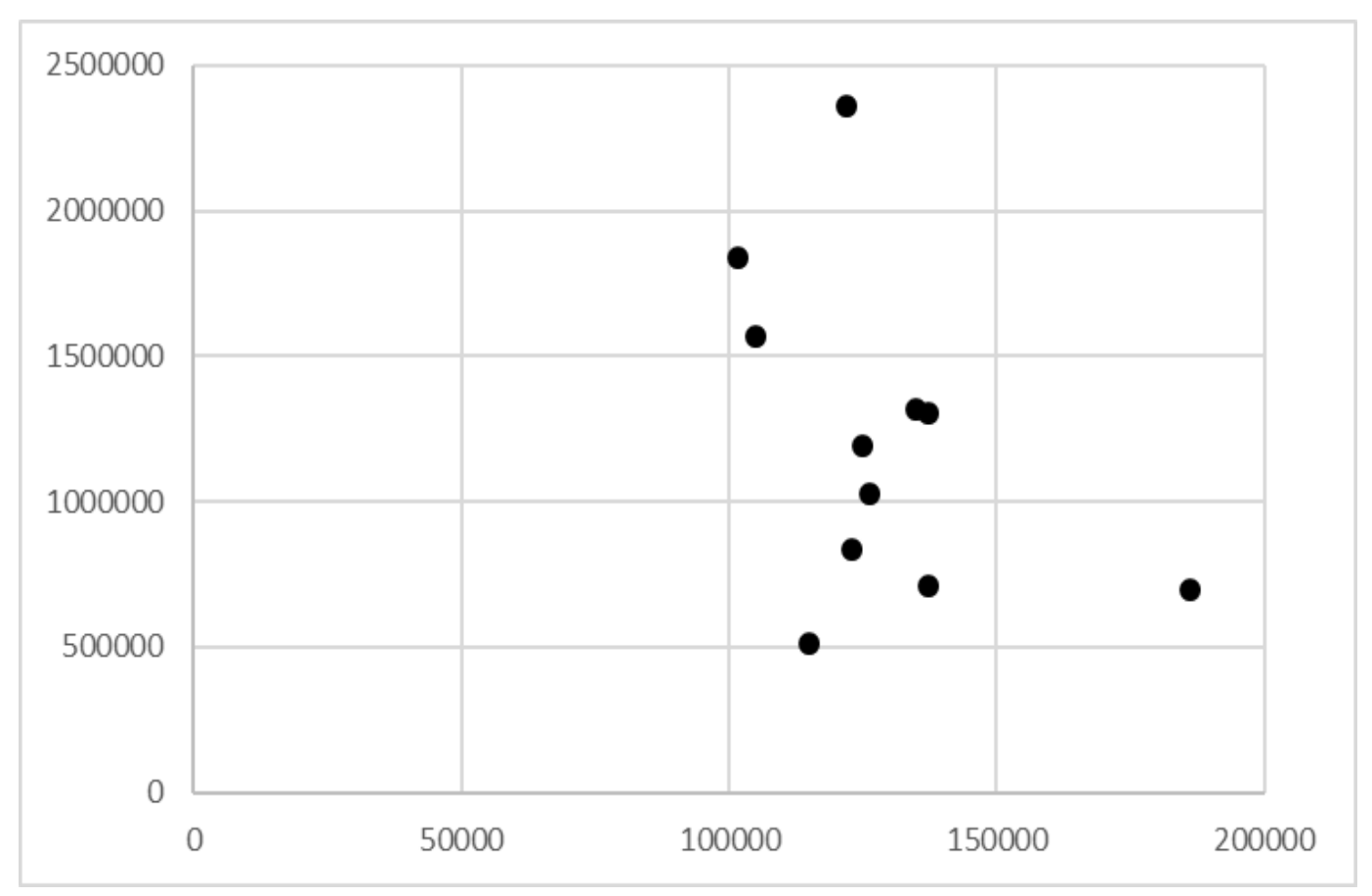

Рис. 2. Залежність рівня споживання населення України від споживчих кредитів Джерело: побудовано на підставі власних розрахунків авторів за даними статистичної звітності (Держстат України, Національний банк України) 
Відсутність лінійної залежності між показниками свідчить, що зміна в споживчому кредитуванні не призводить до відповідного впливу на рівень споживання населення України. Так, збільшення рівня споживання у грошовому виразі у першу чергу обумовлюється інфрляцією, а не збільшенням споживчих кредитів. До того ж у останні 5 років простежується збільшення номінальних доходів населення.

Для порівняльного аналізу наведена залежність рівня споживання від споживчих кредитів у 2007-2017 рр. Республіки Білорусь (рис. 3).

На рис. 3 простежується лінійна залежність між показниками, тобто зростання споживчих кредитів призведе до відповідного зростання споживання населення. Відсутність лінійної залежності показників для України, на наш погляд, в першу чергу обумовлюється політичними чинниками, зниженням безпеки держави та інфляцією.

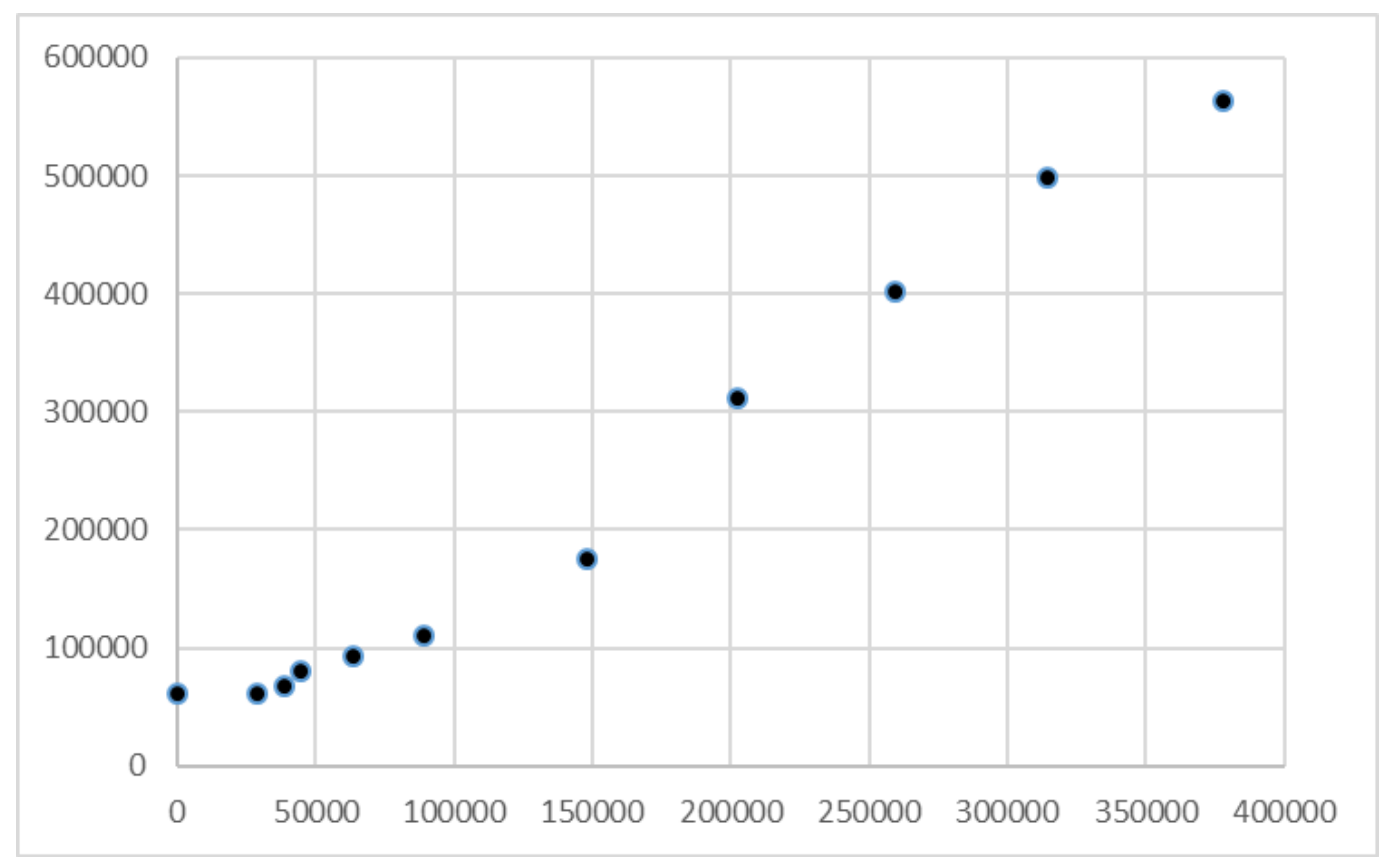

Рис. 3. Залежність рівня споживання населення Республіки Білорусь від споживчих кредитів

Джерело: побудовано на підставі власних розрахунків авторів за даними статистичної звітності (Національний статистичний комітет Республіки Білорусь)

При розширенні банками обсягів споживчого кредитування необхідно враховувати ступінь впливу на рівень споживання доходів населення та споживчих кредитів. Для дослідження цієї залежності доцільно побудувати двохфакторну економетричну модель. Побудуємо експоненціальну модель залежності рівня споживання населення від доходів домогосподарств та споживчих кредитів:

$$
Y=e^{\beta_{0}+\beta_{1} \cdot X_{1}+\beta_{2} \cdot X_{2}}+u
$$

де $Y$ - фактичні значення розмірів споживання товарів та послуг, млн. грн.;

$X_{I}$ - фактичні значення доходів домогосподарств, млн. грн.;

$X_{2}$ - фактичні значення споживчих кредитів, млн. грн.;

$\beta_{0}, \beta_{1}, \beta_{2}$ - невідомі параметри моделі;

$u$ - випадкова величина, що характеризує похибку регресії. 
Побудована модель має наступний вигляд:

$$
Y=e^{12,80473442+0,00000077 \cdot X_{1}+0,00000009 \cdot X_{2}}
$$

Нормований коефіцієнт детермінації $\mathrm{R}^{2}$ побудованої моделі дорівнює 0,9466, що свідчить про ії̈ високу якість (критерій Фішера $\mathrm{F}=89,60597$ є статистично значимим).

Для з'ясування ступеню впливу кожного з факторів приведемо отриману модель до стандартизованого вигляду, а змінні для такої моделі позначимо як $t_{Y}, t_{X_{1}}, t_{X_{z}}$ та отримуємо:

$$
t_{Y}=b_{1} \times t_{X_{1}}+b_{2} \times t_{X_{2}}
$$

Середньоквадратичні відхилення кожної змінної дорівнюють:

$$
\begin{aligned}
& \sigma_{Y}=0,459812537 \\
& \sigma_{X_{1}}=585912,7252 \\
& \sigma_{X_{z}}=22514,18574
\end{aligned}
$$

Отримуємо наступну стандартизовану модель:

$$
t_{Y}=0,9803 \cdot t_{X_{1}}+0,0044 \cdot t_{X_{2}}
$$

Стандартизовані коефіцієнти регресії показують, на яку частину свого середнього квадратичного відхилення зміниться результат $\mathrm{Y}$, у відповідь на зміну окремого фактору, при незмінному впливу інших факторів.

Аналізуючи отримані результати, можна зробити висновок, що зміна обсягів споживчого кредитування на $1 \sigma$ призведе до зміни рівня споживання на 0,0044 $\sigma$. При цьому ступінь впливу споживчого кредитування на рівень споживання за аналізований період у 22 рази менше ступеню впливу доходів населення.

Для порівняльного аналізу та більш детального обґрунтування результатів дослідження побудуємо двохфакторну лінійну модель для Республіки Білорусь:

$$
Y=\beta_{0}+\beta_{1} \cdot X_{1}+\beta_{2} \cdot X_{2}+u
$$

Отримуємо наступну модель:

$$
Y=7750,7755+0,7305 \cdot X_{1}+0,3408 \cdot X_{2}+u
$$

Нормований коефіцієнт детермінації $R^{2}$ побудованої моделі дорівнює 0,9975, що також свідчить про її високу якість (критерій Фішера $F=1981,612$ є статистично значимим).

Середньоквадратичні відхилення кожної змінної дорівнюють:

Стандартизована модель має вид:

$$
\begin{aligned}
& \sigma_{Y}=189719,8175 \\
& \sigma_{X_{1}}=200279,3569 \\
& \sigma_{X_{2}}=128344,2902
\end{aligned}
$$

$$
t_{Y}=0,7712 \cdot t_{X_{1}}+0,2306 \cdot t_{X_{2}}
$$

Співставлення стандартизованих коефіцієнтів регресії вказує, що ступінь впливу доходів домогосподарств Республіки Білорусь лише у 3,34 рази перевищує споживче кредитування. Тобто в Україні вплив доходів домогосподарств на рівень споживання в 1,27 рази більше ніж в Республіці Білорусь, а вплив споживчого кредитування в 52 рази менше.

Висновки. Спираючись на проведений аналіз, можна зробити висновки, що починаючи 3 2016 року простежується збільшення схильності населення України до споживчого кредитування. Населення прагне подолати наслідки інфрляції та використовує споживчі кредити для покупки товарів на тривалий час. У свою чергу, відповідні кредитні зобов'язання, на наш 
погляд, обумовлюють підвищення економічної активності населення, що взагалі сприяє економічному зростанню країни. Таким чином, банківському сектору необхідно продовжувати розширювати свою кредитну експансію за рахунок введення нових банківських продуктів та послуг та працювати у напрямі підтримання сприятливого ставлення до банківської сфери населення України. На наш погляд, запропонована економетрична модель залежності рівня споживання від споживчого кредитування та доходів домогосподарств дасть змогу банкам оптимізувати свою кредитну експансію та обґрунтовувати прогнозні значення розмірів споживчих кредитів.

\section{Література}

1. Державна служба статистики України. URL: http://ukrstat.gov.ua.

2. Дорошенко Н.О. Ризики в кредитній діяльності банків. Вісник Харківського національного університету імені В.Н. Каразіна, серія "Економічна". Харків, 2018. № 95. С. 23-29.

3. Меркулова Т.В., Коваль Б.С. Довіра та соціально-економічні показники: модель 3 урахуванням фактора релігії. Вісник Харківського національного університету імені В.Н. Каразіна, серія "Економічна". Харків, 2018. № 94. С. 29-35.

4. Міністерство фінансів України. URL: https://minfin.com.ua.

5. Мороз К.В. Розподіл грошових доходів населення україни: емпіричний аналіз 3 використанням логнормальної функції. Вісник Харківського національного університету імені В.Н. Каразіна, серія "Економічна". Харків, 2016. № 91. С. 110-117.

6. Национальный статистический комитет Республики Беларусь. URL: http://www.belstat.gov.by.

7. Національний банк України URL: http://www.bank.gov.ua.

8. Рябініна Л.М. Кредитна експансія та її вплив на економіку України. Економіка України. Київ, 2016. № 3(652). С. 41-51.

9. Швайко М. Л. Сучасні тенденції грошово-кредитної політики України. Вісник Харківського національного університету імені В.Н. Каразіна, серія "Економічна". Харків, 2017. № 92. С. 32-40.

\section{References}

1. State Statistics Service of Ukraine. Retrieved from http://ukrstat.gov.ua.

2. Doroshenko, N. (2018). Risks in bank lending activity. Bulletin of V. N. Karazin Kharkiv National University Economic Series, 95, 23-29. (In Ukrainian)

3. Merkulova, T., Koval, B. (2018). Trust and socio-economic indicators: model including religion factor. Bulletin of V. N. Karazin Kharkiv National University Economic Series, 94, 29-35. (In Ukrainian)

4. Ministry of Finance of Ukraine. Retrieved from https://minfin.com.ua.

5. Moroz, K. (2016). Income distribution of the population of Ukraine: empirical analysis using lognormal function. Bulletin of V. N. Karazin Kharkiv National University Economic Series, 91, 110-117. (In Ukrainian)

6. National Statistical Committee of the Republic of Belarus. Retrieved from: http://www.belstat.gov.by.

7. National bank of Ukraine. Retrieved from http://www.bank.gov.ua.

8. Ryabinina, L. (2016). Credit expansion and its influence on Ukraine's economy. Economy of Ukraine, №3 (652), 41-51. (In Ukrainian)

9. Shvayko, M. (2017). Current trends of monetary policy of Ukraine. Bulletin of V. N. Karazin Kharkiv National University Economic Series, 92, 32-40. (In Ukrainian) 